\title{
The Impact of the Announcement of Acquisition of Divested Assets on Buyers' Wealth - Asset Fit and Disclosure of Funds Used: Evidence from the U.K.
}

\author{
Balasingham Balachandran \\ Monash University, Australia \\ Robert Faff \\ Monash University, Australia \\ Roger Love \\ Monash University, Australia \\ Andrew Menon \\ Monash University, Australia
}

This study examines the effects of announcements of acquisition of assets on shareholder wealth of buyers over the period January 2000 to December 2002 in the U.K. Significant positive announcement period abnormal returns for "fit' acquisitions of divested assets that disclosed the "sources of funds" are documented. Multivariate regression analysis shows that announcement period abnormal returns are significantly related to pre-announcement period abnormal returns, relative size of the acquisitions and disclosure of sources of funds. Overall, there is little or no support for the asset fit hypothesis. However, there is strong support for "Fund Source Disclosure", "Fund Source Pecking-Order" and "Relative Size of Acquisition" Hypotheses (JEL: G34).

Keywords: divested asset acquisition; buyers; price reaction; fit and non-fit; fund source

\section{Introduction}

A growing range of studies have examined the impact of the announcement of divested asset sales (division of a firm) on sellers' shareholders wealth in the U.S. and U.K. (see for example, Rosenfield

\footnotetext{
* The first author would like to thank the grants received from Faculty of Business and Economics, Monash University in 2001.
}

(Multinational Finance Journal, 2008, vol. 12, no. 3/4, pp. 219-240)

Quarterly publication of the Multinational Finance Society, a nonprofit corporation. (C) Global Business Publications. All rights reserved.

DOI: $10.17578 / 12-3 / 4-4$ 
[1984], Hite, Owers and Rogers [1987], Jain [1985], John and Ofek [1995], Lang, Poulsen and Stulz [1995] and Slovin, Sushka and Ferraro [1995] in the U.S.; and Afshar, Taffler and Sudarsanam [1992], Lasfer, Sudarsanam and Taffler [1996], Clubb and Stouraitis [2002] and Alexandrou and Sudarsanam [2001] in the U.K.). Such studies show that announcement of asset sales results in a positive effect on shareholders' wealth. For example, Hite, Owers and Rogers (1987) argue that asset sales promote efficiency by allocating assets to better uses, and sellers capture some of the resulting gains (efficient deployment hypothesis of asset sales). Interestingly, Lang, Poulsen and Stulz (1995) document a positive (negative) sellers' impact where the proceeds are used to pay out creditors and shareholders (are retained). However, the empirical evidence on of the impact of asset sales on buyers wealth is limited to only U.S. studies (see for example, Rosenfield [1984], Jain [1985], Hite, Owers and Rogers [1987], Sicherman and Pettway [1992], and John and Ofek [1995]).

Rosenfeld (1984) found average abnormal return of $2.1 \%$ for the three-day event period surrounding the announcement of acquisition of assets for a sample of 30 U.S. acquisitions. He suggests that the asset sell off decision is perceived by sellers and buyers as a positive net present value transaction. Jain (1985) documents significantly positive abnormal returns of $0.34 \%$ on the day before the announcement of asset sales on buyers' wealth. Zaima and Hearth (1985) found insignificant abnormal returns over various event windows for 75 firms that acquired divested assets. Hite, Owers and Rogers (1987) found that 51 successful buyers experienced significant positive gains of $0.83 \%$ at the announcement of an asset acquisition for a two-day announcement period. Sicherman and Pettway (1987) found that the purchase of related assets provides positive abnormal buyers' returns around the announcement date. John and Ofek (1995) argued that buyers will experience additional value, created by more efficient utilisation of acquired assets, because the acquired asset 'fits' with (or is related to) its existing core operations. However, they found insignificant price reaction for buyers. They explained this result by suggesting that buyers' neither gain nor lose from acquisition of divested assets and that on average, all the gains created by assets sales are captured by sellers.

Sicherman and Pettway (1992) found that buyers experienced significantly positive abnormal return of $0.82 \%$ when the transaction prices were disclosed and insignificant abnormal when the prices were not revealed. As a result, the authors drew the inference that buyers' shareholders "react more favorably to sell-off announcements if the transaction prices are revealed". More generally, Slovin, Sushka and 
Ferraro (1995) noted that a sell-off usually entails little disclosure. This highlights the importance of the informational content of the announcement to mitigate asymmetric information. One important type of potential information is the source of funds used by buyers' for the acquisitions. As such, non-disclosure of fund sources contributes to asymmetric information, and it is argued that this will generally lead to less favorable reactions from buyers' shareholders because in these circumstances the market perceives management to be hiding unfavorable information. No previous studies have looked at this issue. Three main sources for funding asset purchases are: existing cash; debt or equity; and in the current study the aim is to seek to disentangle the potential differential price reaction with regard to each of these alternate sources.

This study supplements the U.S. evidence on the impact of assets sales on buyers' wealth with analysis of a U.K. sample. No studies have examined the impact of the disclosure of the sources used to acquire divested assets on buyers' wealth. As such, the evidence in the buyers' wealth literature is enhance by examining the impact of disclosure of sources of funds used versus non-disclosure of funds used and its relationship with fit versus non-fit acquisition of assets. It is expected that the market rewards the revelation of information and, accordingly, that it will react strongly positive to the announcements of those acquisitions that disclosed the sources of funds.

The paper proceeds as follows: Section II presents testable hypotheses and a description of the research design; Section III details the results and findings; finally, in Section IV a conclusion is provided.

\section{Empirical Framework}

\section{A. Data and Sample}

The U.K. sample of sell-off announcements covers the period January 2000 to December 2002 and three criteria are required for inclusion. First, announcement dates of asset acquisition were obtained from the Bloomberg database. Second, the sample only includes completed asset acquisitions for pure cash consideration. Third, buyers had to be listed companies with share price data available in Datastream for the period from 520 days before the announcement date to 2 days after the announcement date. ${ }^{1}$ Starting from a potential sample of 196, the final

1. Partial and 'staged' asset acquisitions of divested assets were eliminated from the sample because the market would have previously captured this information in the share price. 
TABLE 1. Sample Description

Panel A: Summary of data filtering

Initial announcement details of acquisition

of assets obtained from Bloomberg 196

Less

$100 \%$ divestment of ownership of a division -23

acquisition of divested assets undertaken in stages $\quad-3$

Unlisted buyers -6

Share price data not unavailable in Datastream $\quad-22$

Final Sample $\quad 142$

Panel B: Sub-samples

Fit acquisition and Sources of funds disclosed $\quad 52$

Fit acquisition and Sources funds Not-disclosed $\quad 68$

Non-Fit acquisition and Sources of funds disclosed $\quad 7$

Non-Fit acquisition and Sources funds not-disclosed $\quad 15$

Panel C: Industry Sub-samples

Basic Materials

Consumer Goods $\quad 15$

Consumer Services $\quad 43$

Financials 1

Healthcare $\quad 15$

Industrials $\quad 33$

Oil \& Gas 4

Technology 9

Telecommunications $\quad 5$

$\begin{array}{ll}\text { Utilities } & 10\end{array}$

Note: This table provides some brief descriptive details regarding the sample used. Panel A describes the data filtering process. Panel B summaries sub-samples in terms of whether acquisitions were classified as 'fit' or 'not fit' and whether the funding source was revealed or not. Panel $\mathrm{C}$ describes the industry breakdown of the sample.

sell-off sample consists of 142 buyers. A summary of data filtering and Asset Fit/ Disclosure of Funds sub-samples is provided in panel A of table 1. Panel B of that table shows that most acquisitions are 'fit' with a slight majority of these not disclosing the source of funding. Finally, panel $\mathrm{C}$ of this table shows that most of the buyers are in the consumer goods, consumer services, healthcare and industrials industries.

To provide further preliminary background for the sample employed prior to moving on the main analysis, in table 2 some descriptive statistics organized around three sets of univariate tests are presented. In panel A some basic univariate tests of the difference in the medians of a range of relevant variables, between the fit and non-fit acquisition categories in the sample are reported. The variables examined are: 


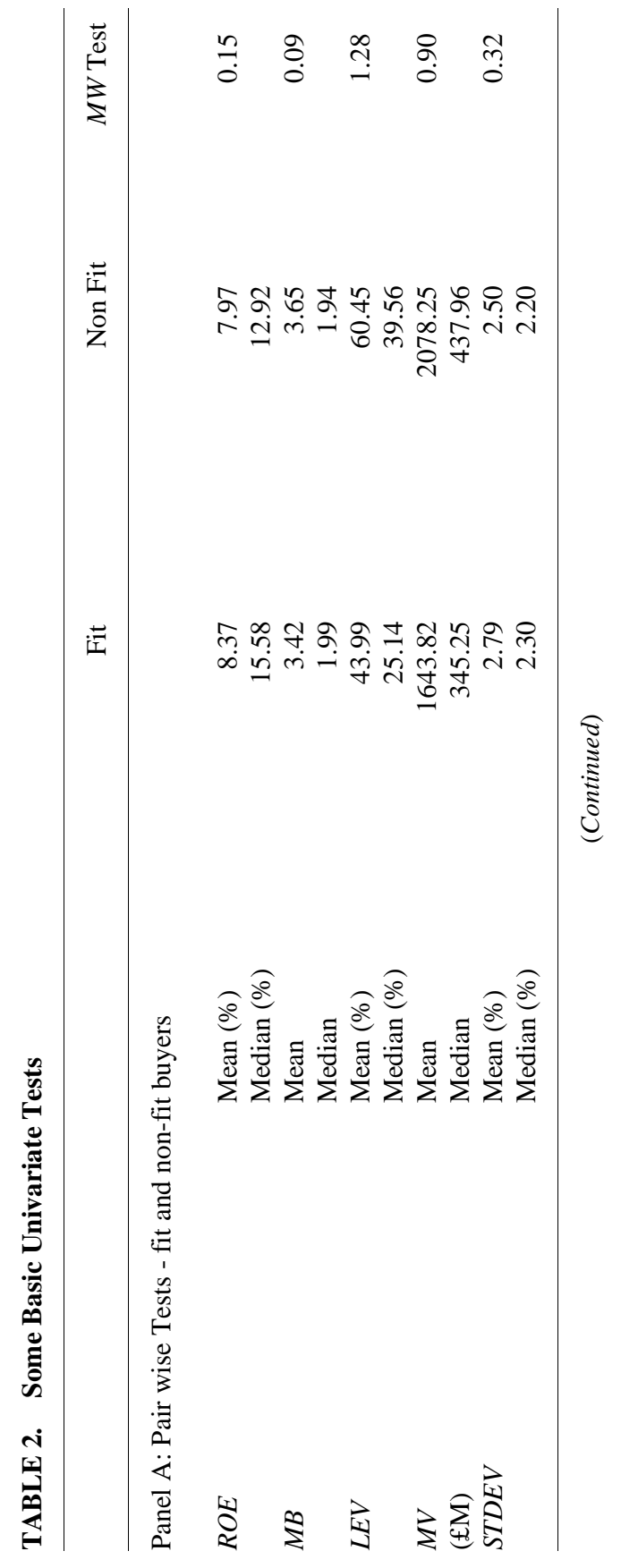




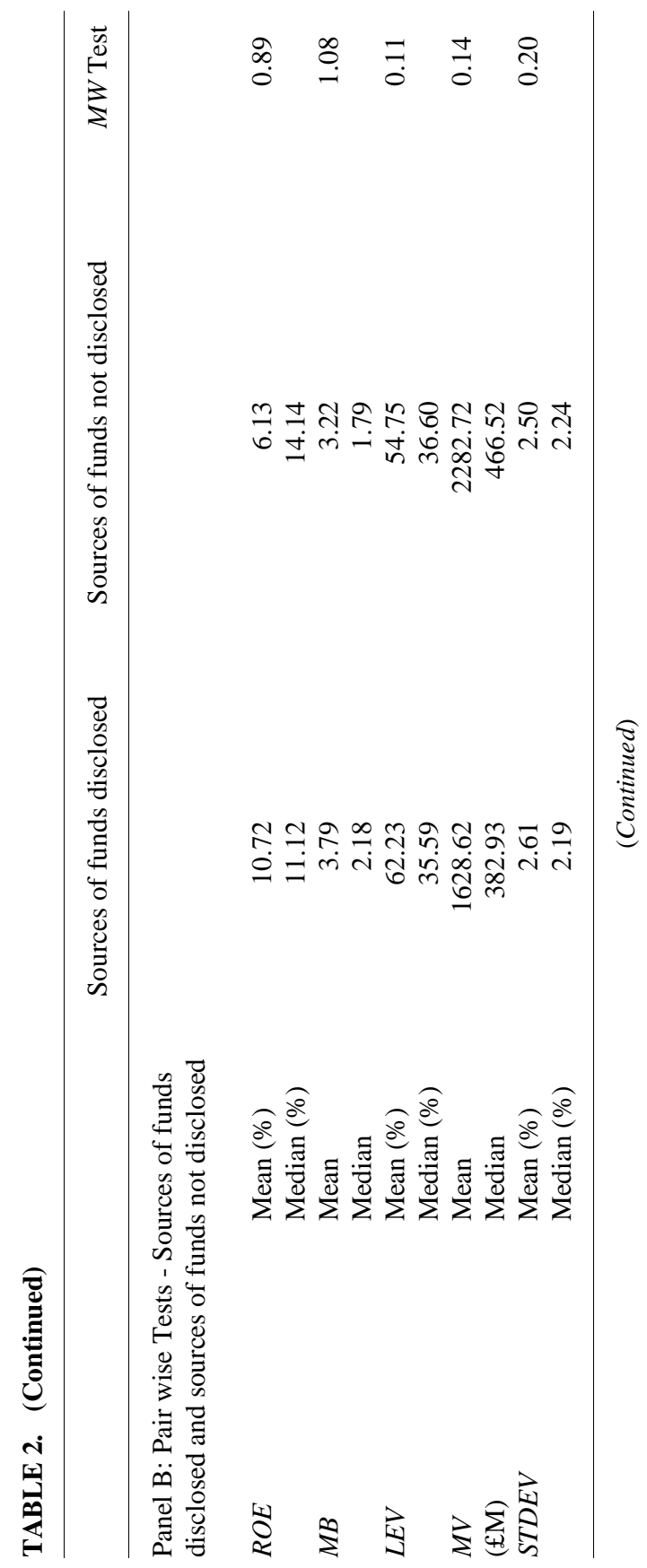




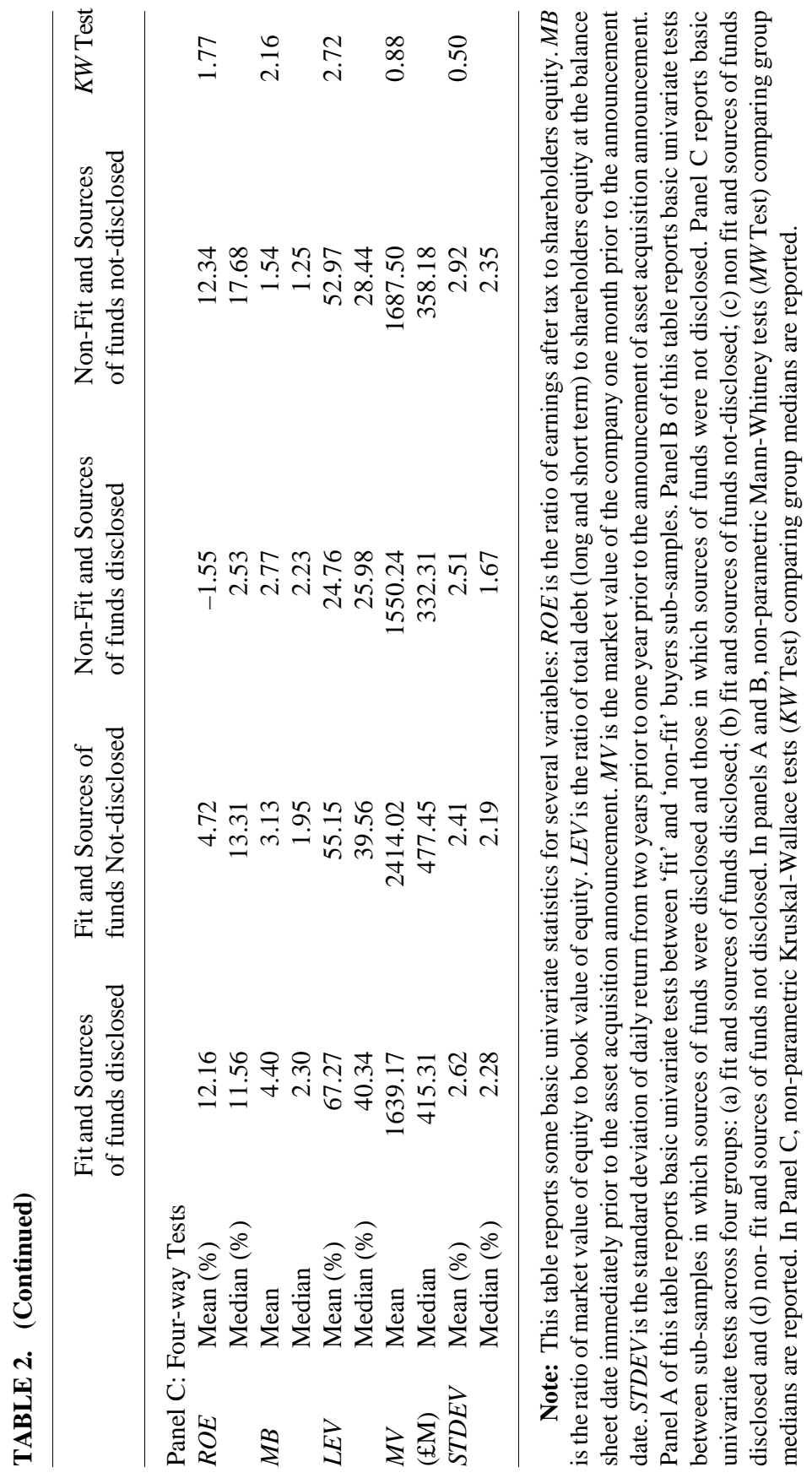


return on equity $(R O E)$; market to book value of equity $(M B)$; leverage $(L E V)$; market value of equity $(M V)$; standard deviation of daily returns $(S T D E V)$. Similarly, in panel B some basic univariate tests of the difference in the medians across the same set of variables are reported, this time partitioning the sample into those cases for which the sources of funds were disclosed versus those for which the sources of funds were not disclosed. Generally, based on the non-parametric Mann-Whitney tests, there is no significant differences across all variables - either between fit versus non fit or between sources of funds disclosed versus sources of funds not disclosed.

Panel $\mathrm{C}$ of table 2 reveals an extended set of univariate tests, this time comparing across four blended categories: (a) fit and sources of funds disclosed; (b) fit and sources of funds not disclosed; (c) non-fit and sources of funds disclosed; and (d) non-fit and sources of funds not disclosed. As above, there is no significant differences across all variables (based on non-parametric Kruskal-Wallace tests).

One final comment is warranted on the preliminary statistics with regard to the market to book ratio of all firms included in the sample. Irrespective of the fit/non-fit/disclosure/non-disclosure distinctions, the $M B$ is relatively high - for example, in panel A of table 2 it is seen that fit (non-fit) sample firms have a mean $M B$ of 3.42 (3.65). This suggests that companies which turn out to be buyers of divested assets tend to be growth firms - an intuitively appealing result, since it suggests that such purchases are one manifestation of their "growth" status.

\section{B. Generation of Abnormal Returns and Test Statices}

Abnormal returns are generated by the market model, whereby its parameters are estimated using logarithmic returns for 520 days prior to 261 days prior to the announcement date. Price reaction is reported for the day before to the day after the announcement date (day -1 to day 1) and from the announcement date to the day after the announcement date (day 0 to day 1). Pre-announcement period abnormal returns are reported for 260 days before the announcement date to 2 days before the announcement date (day -260 to day -2 ). The market proxy applied is Financial Times All Share Price Index.

When testing for the statistical significance of abnormal returns, Brown and Warner (1985) suggested that there will be "substantial increases" in the variance of a security return around the event dates which may cause the $t$-statistic to be over-estimated and lead to a more frequent rejection of the null hypothesis. To overcome this phenomenon of event induced variances, the Standardised Cross Sectional $t$-test $(S C S T)$ is used which effectively normalises the conventional $t$-test by 
the standard deviation of the daily returns for the estimation period (Boehmer, Musumeci and Poulsen [1991]). The parametric $t$-test and Mann-Whitney test are used to assess the difference in mean/median reaction between two sub-groups.

\section{Testable Hypotheses}

In light of the above discussion, a number of hypotheses are investigated. The initial hypothesis will examine the unconditional announcement wealth effects of voluntary sell-offs on buyers' shareholders:

Hypothesis $H_{1}$ : Shareholders of buying firms benefit from acquiring sell-off assets.

The subsequent four hypotheses involve conditional tests that invoke various (theoretically induced) characteristics that have been shown to impact on announcement returns.

Hypothesis $\mathrm{H}_{2}$ : "Asset fit" Hypothesis

The asset 'fit' theory implies that buyers will experience additional value, created by more efficient utilization of acquired assets, because the acquired asset 'fits' with (or is related to) its existing core operations (John and Ofek, 1995). Therefore, larger positive abnormal returns should be apparent where the acquired asset is one that complements the already existing core assets of the buyer as opposed to cases in which a 'non-fit' acquisition of asset has occurred. Accordingly, the $\mathrm{H}_{2}$ hypothesis prediction is: an asset 'fit' acquisition will result in larger positive announcement returns than a 'non-fit' acquisition.

Hypothesis $\mathrm{H}_{3}$ : "Fund Source Disclosure" Hypothesis

Klein (1986) documents that the disclosure of transaction prices at sell-off announcements impacts selling firms' shareholders wealth. This highlights the importance of the informational content of the announcement to mitigate asymmetric information. Sicherman and Pettway (1992) argue that failure to disclose all information leads the uninformed to rationally expect undisclosed information to be unfavourable. Therefore, it is argued that failure to disclose the sources of funds used to finance the acquisition of assets will generally lead to less favourable reactions from shareholders. Hence, the $H_{3}$ hypothesis prediction is: buyers who disclose the source of acquisition funds will experience larger positive announcement returns than buyers who do not disclose the source of acquisition funds.

Hypothesis $H_{4}$ : "Fund Source Pecking-Order" Hypothesis 
Using outside funds for an acquisition of assets may be costly because of the adverse selection costs modelled Myers and Majluf (1984). The cost of outside funds may be high because of the agency costs of managerial discretion (see, for example, Jensen [1988] and Stulz [1990]). Myers (1984) and Myers and Majluf (1984) argue that because of asymmetric information and signalling problems associated with external funding, firms financing policies follow a hierarchy, with a preference for internal over external finance, and debt over equity. Therefore, companies seek to maintain spare debt capacity and exhibit a financial hierarchy: (a) internal financing; (b) external financing raised by borrowing; (c) external funds raised by issuing ordinary shares. This sequence reflects the relative costs associated with addressing the perceived information asymmetry. Therefore, acquisition of assets funded by existing cash flow should experience greater positive announcement returns than funded by new debt, which in turn should be greater than the announcement of acquisition of assets funded by new equity.

Therefore, the $\mathrm{H}_{4}$ hypothesis prediction is: the acquisition of assets that are funded by existing cash will experience larger positive announcement returns than counterparts funded by new debt, which in turn will have a greater market reaction than that induced by asset acquisitions funded by new equity.

Hypothesis $H_{5}$ : "Relative Size of Acquisition" Hypothesis Asquith, Bruner and Mullins (1983) documented a direct association between a bidder's abnormal returns and the target buyer's relative size in the mergers and takeover literature. Additional support for this size hypothesis was provided by Jarrell and Poulsen (1989); Hayn (1989); Morck, Shleifer and Vishny (1990); and Walker (2000). Therefore, the $\mathrm{H}_{5}$ hypothesis prediction is: it is expected that the size of the acquired asset relative to the buying firm's total size is directly associated with announcement returns.

\section{Results}

\section{A. Event Study Results}

Panel A of table 3 (column headed "All”), reports the abnormal returns for the full sample of buyers, thereby testing hypothesis $H_{1}$. It is found that the buyers' abnormal returns of the full sample of acquisition of divested assets are insignificantly different from zero, hence, hypothesis $H_{1}$ is not supported by the data. While this is disconcerting, it doesn't invalidate the need to explore the other conditional hypotheses since 


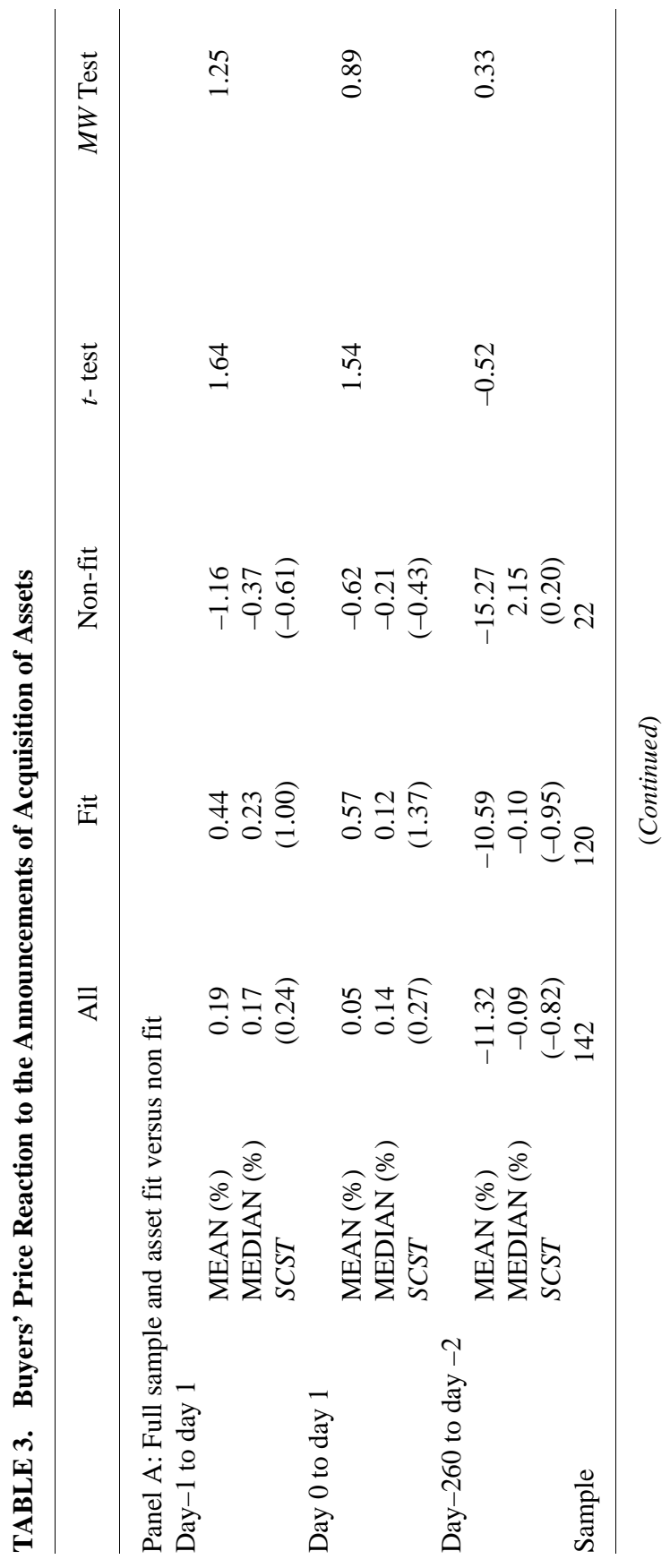




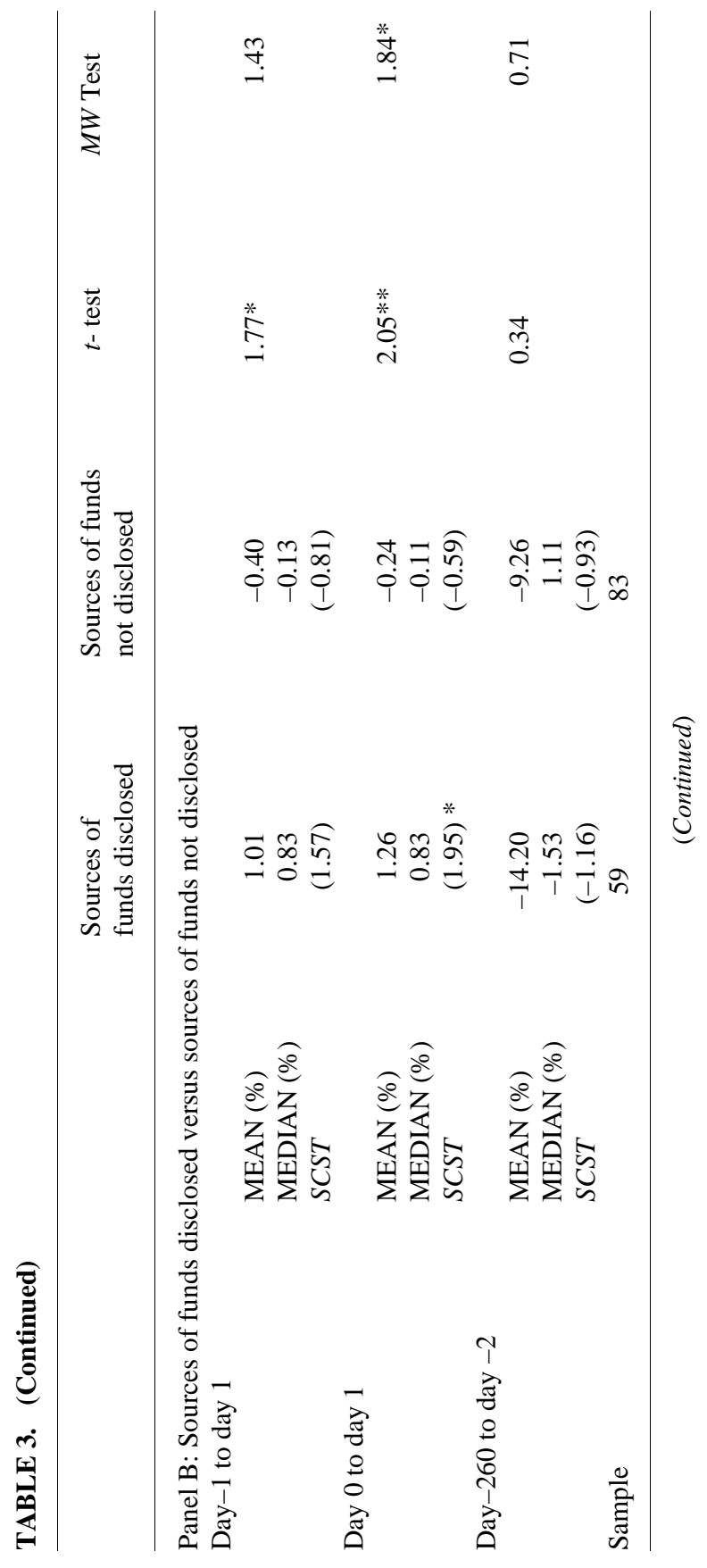




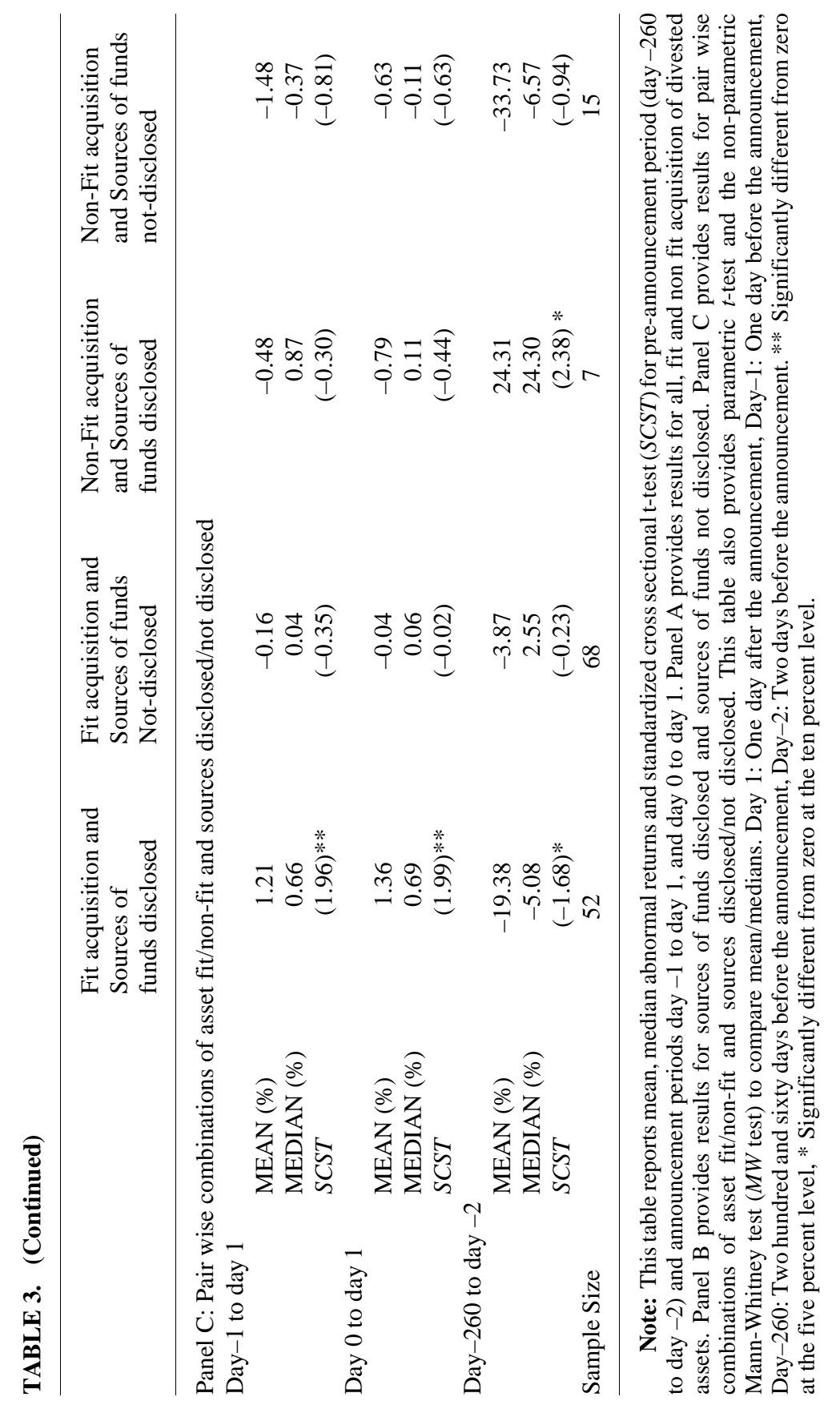


there may be countervailing factors that mask the price impact at the unconditional level. This extended analysis is now considered.

The remaining columns of panel A of table 3 report the abnormal returns for the asset 'fit' and 'non-fit' sub-samples, thereby aiming to shed light on hypothesis $H_{2}$, the "asset fit" hypothesis. The overwhelming result coming from this table is that the short window event response is negligible and insignificant for both fit and non-fit acquisitions. Moreover, the two price reactions are not significantly different from each other. Having said that, there is a weak suggestion that the price impact occurs in the direction hypothesized by $\mathrm{H}_{2}$ i.e., favoring fit over non-fit acquisitions. Panel B of table 3 reports the abnormal returns partitioned between those acquisitions that disclosed the funds used $(N$ $=59)$ and those in which funds used were not disclosed separately $(N=$ 83) to shed light on hypothesis $H_{3}$, the "fund source disclosure" hypothesis. The results support this hypothesis strongly. Specifically, the day 0 to day +1 abnormal return for the sample of buyers disclosing the funds used is significantly positive at $1.26 \%$. Moreover, tests of equality in means and medians between the sources disclosed versus not disclosed groups are rejected, in favor of a superior abnormal return for the former group. Hence, fund source disclosure does seem to matter for the sample, and notably the findings are consistent with disclosure helping to alleviate information asymmetry.

To further tease out whether a potential effect is in evidence, the abnormal returns are partitioned into combinations of fit versus non-fit and source disclosed versus source not disclosed-that is, into the four groups emanating from the intersection of these classifications. The outcome of this analysis is reported in panel $\mathrm{C}$ of table 3 . The major finding here is that asset fit acquisitions, for which the source of funding is disclosed, produce significantly positive abnormal returns at the 5\% level (for both short window measures). For example, the two-day short window event period abnormal return (day 0 to day +1 ) is estimated at $1.36 \%$. The second finding revealed in this table for the same subgroup is the significance (at the 10\% level) of the longer window pre-event price reaction (-260 to -2$)$. Indeed, estimated with a value of $-19.4 \%$, this is economically important, indicating that these buyers were experiencing poor performance for a considerable period prior to the asset purchase.

\section{B. Cross-sectional Regression Model}

To further test the set of conditional hypotheses, $H_{2}$ to $H_{5}$, a crosssectional regression analysis is performed. The dependent variable 
(CAR) is the two-day abnormal return from day 0 to day 1 . The set of explanatory variables and their anticipated signs (in parentheses) are outlined below.

DFIT (+) is a dummy variable indicating that a 'fit' sell off has occurred. Specifically, DFIT takes the value of unity when the buyer acquires an asset that 'fits' with its existing core assets, and zero, if the acquired asset is deemed a 'non-fit' (i.e., does not complement the already existing core assets of the buyer) acquisition. A 'fit' acquisition is deemed (not) to have occurred when the GICS code (level 3) of the target matches (doesn't match) the GICS code of the buyer. ${ }^{2}$ It is expected that DFIT has a positive effect on buyers' CAR. This variable accommodates hypothesis $H_{2}$.

DSOF (+) is a dummy variable that takes the value of unity when buyers disclose the information pertaining to the source of acquisition funds and zero otherwise. Guided by the argument that the market rewards cases where asymmetric information is mitigated, the anticipated sign of this independent variable is positive. This variable accommodates hypothesis $\mathrm{H}_{3}$.

DFITSOF (+) is an interactive variable between DFIT and DSOF. This variable is created to capture the reinforcing effect of hypotheses $\mathrm{H}_{2}$ and $H_{3}$, and as such, will maximise their power. It is predicted to have a positive impact.

$D L O A N$ is a dummy variable that takes the value of unity when buyers disclose (at the time of announcement) that the source of funds for the acquisition of divested assets as a loan, and zero otherwise.

DEQUITY is a dummy variable that takes the value of unity when buyers disclose (at the time of announcement) that they will issue new equity to fund the acquisition of divested assets, and zero otherwise. $D E X C A S H$ is a dummy variable that takes the value of unity when buyers disclose (at the time of announcement) that they will use existing cash to fund acquisition of divested assets, and zero otherwise.

RSIZE (+) represents relative size of buyers. It is measured as the sell-off price divided by the market value of buyers (Klein [1986]), on the last trading day of the month prior to the announcement. This variable accommodates hypothesis $H_{5}$.

$L M V(-)$ is the natural logarithm of the market value of the company one month prior to the announcement date. In general, smaller companies tend to be less extensively analyzed and less information is generally available for such companies. In the absence of a large

2. GICS classifies companies into 59 sub-industries. 
number of information sources, price reactions would be anticipated to be relatively larger for smaller companies. Hence, the sign of the coefficient of this variable will be negative.

PRECAR (-) is the pre-announcement cumulative abnormal return from day -260 to day -2 .

$L E V(+)$ is the ratio of total debt (long and short term debt) to shareholders equity at the balance sheet date immediately prior to the asset acquisition announcement. The acquisition of divested assets alters the mix of risky and riskless assets held by buyers. For this reason, private lender monitoring plays a key role in determining the net gains from asset acquisitions. Datta, Iskandar-Datta and Raman (2003, p. 353) document that effective monitoring is important and significantly benefits the shareholders of the buying firm as the "problems associated with over-investment and free cash flow are likely to be ameliorated". Consequently, the buyers, who are monitored by private lenders, are less likely to misallocate finances and erode value. $L E V$ is a control variable and therefore it is expected that its coefficient will be positive.

$M B$ is the ratio of market value of equity to book value of equity. This is a control variable and is used as a proxy for the extent and quality of investment/growth opportunities as firms with good investment opportunities maximize shareholder value by using internal cash flow or external financing to finance investment.

$R O E$ is the ratio of earnings after tax to shareholders equity. This variable is used as a control variable.

$S T D E V$ is the standard deviation of daily return from two years prior to one year prior to the announcement of asset acquisition. This is a control variable and is used as a proxy for the risk of the firm.

The results of this estimation are reported in table 4. A number of key features are evident from the table. First, the regression models in the table demonstrate that, by virtue of an insignificant DFIT coefficient, there is insufficient evidence to support the asset fit hypothesis $\left(\mathrm{H}_{2}\right)$. Second, model 2 shows that buyers' CAR is significantly positively impacted (at the $5 \%$ level) by the disclosure of the source of acquisition funds. This finding supports the "Fund Source Disclosure" hypothesis $\left(H_{3}\right)$, which leads us to infer that disclosure regarding the source of acquisition funds augments buyers' CAR as information asymmetry is mitigated. Third, in an attempt to explore the reinforcing impact of asset fit and disclosure, model 3 includes an interaction term for these effects and finds its coefficient to be positive and significant, as expected.

Fourth, models 5 and 6 include the disaggregated funding source 


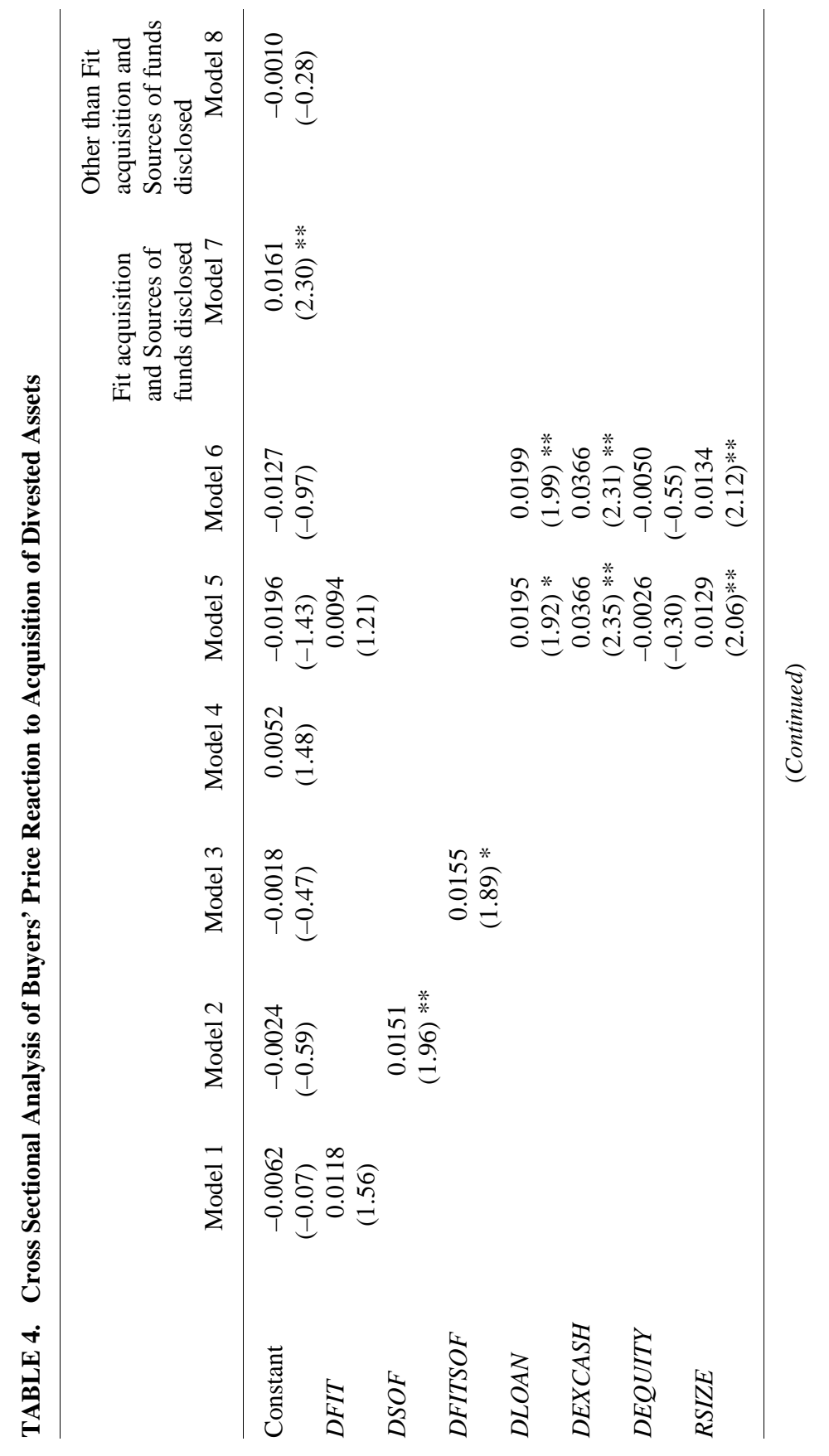




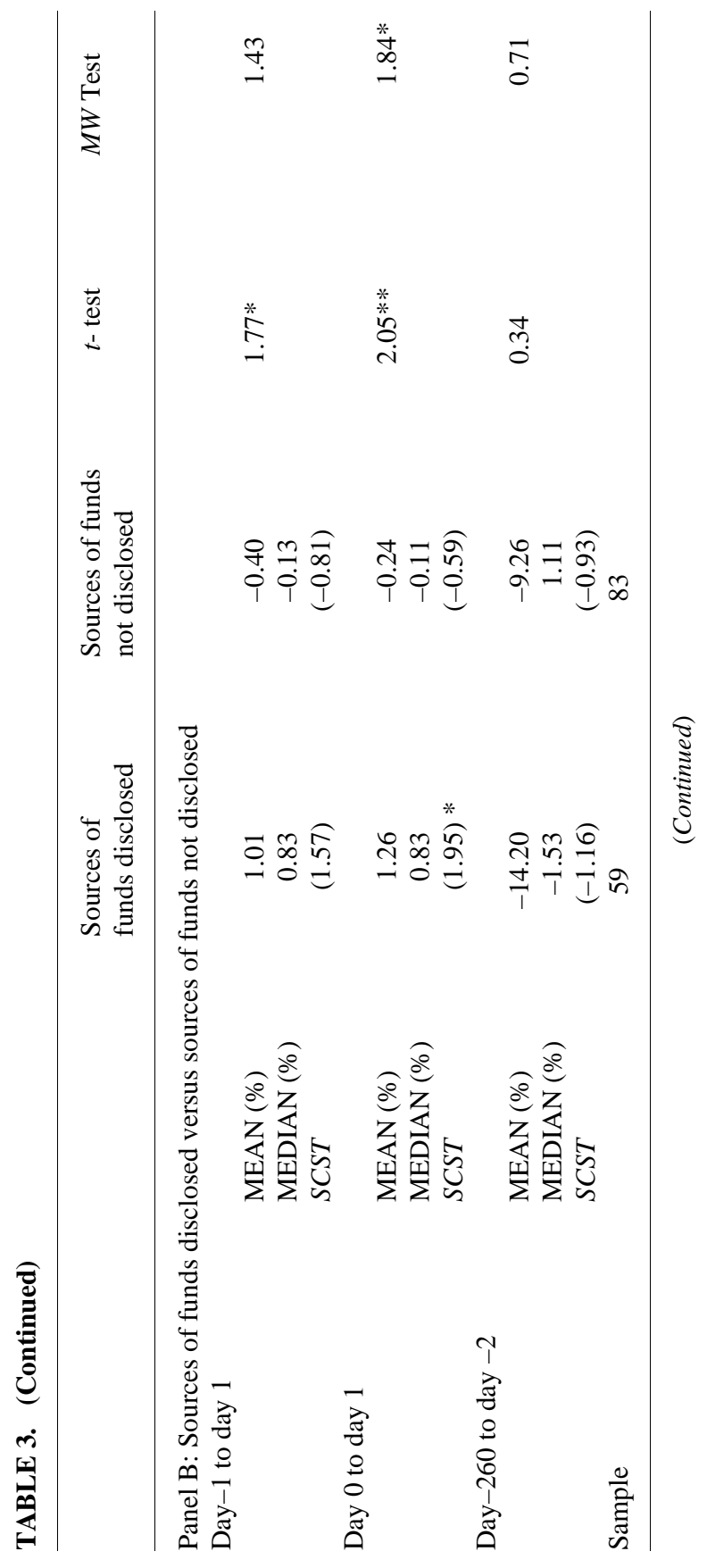




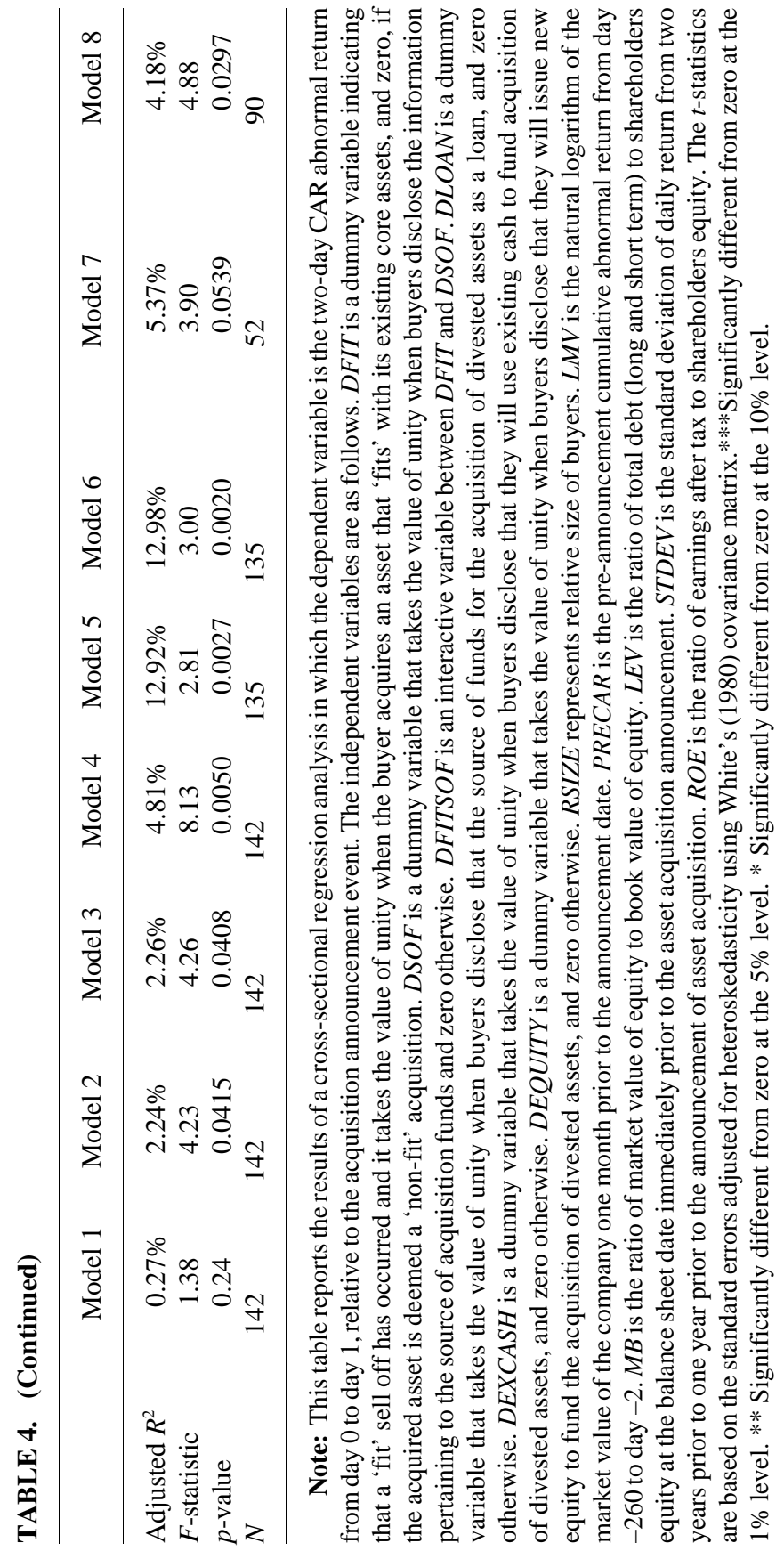


disclosure dummy variables: DLOAN; DEXCASH and DEQUITY. Interestingly, it is observed that the cash and debt disclosure variables are both positive and statistically significant at the 5\% and $10 \%$ levels, respectively. Specifically, acquisitions that involve disclosure of cash (debt) as the source of funding generate an additional average abnormal price impact of $3.7 \%(2.0 \%)$. The detection of source of acquisition funds by way of loans having a positive effect on buyers' CAR suggests that the market showed preference for increased levels of private lender monitoring. This result is consistent with the findings in Datta, Iskandar-Datta and Raman (2003). Fifth, with regard to "fund source pecking order" hypothesis, comparing the coefficient estimates on the disaggregated source dummy variables, a ranking predicted by $H_{4}$ : CASH > LOAN > EQUITY is observed. This result suggests that managers do apply a pecking order philosophy to choosing the means by which they fund asset acquisitions.

Sixth, the coefficient on RSIZE is positive and statistically significant (at the 5\% level) in models 5 and 6 . This finding supports $H_{5}$ - the "relative size of acquisition" hypothesis-namely, that the larger the relative size of the acquisition, the greater the positive price impact. Seventh, the result observed in models 4 to 6 in table 4 is that PRECAR has a positive and significant coefficient (at the 5\% level). This finding is puzzling since a significantly (10\% level) negative reaction for the pre-announcement period abnormal returns for the fit acquisition that disclosed their sources of funds was found (refer to panel $\mathrm{C}$ of table 3 ). Therefore, the relationship between announcement period abnormal return and PRECAR for the fit acquisitions that disclosed their sources of funds and others separately was examined. The results are reported in models 7 and 8 and they show that announcement period return is positively related to pre announcement returns. A plausible reason for these findings may be that the least poor performers during the pre announcement period react strongly positively during the announcement period. Finally, it is noted that the range of control variables used $(L M V$; $M B ; L E V ; S T D E V$ and $R O E$ ) are all statistically insignificant.

\section{Summary and Conclusion}

This study examines the effects of announcements of voluntary sell-offs of divested assets on buyers' shareholder wealth in the U.K. over the period January 2000 to December 2002. When the sample is partitioned into the disclosure of sources of funds used versus non disclosure, a 
significantly positive average price reaction of $1.26 \%$ for the announcement period from day 0 to day 1 and a negative but insignificant reaction for non-disclosure of funds was found. It was also found that these two groups' reactions differ significantly from each other. Upon partitioning between combinations of 'fit' versus 'non-fit' and sources of fund disclosed versus non-disclosed, significantly positive reaction is found only for fit acquisitions that disclose the sources of funds. It was also found that significantly negative price reactions occur for one year prior to the acquisition for fit acquisitions that disclose the sources of funds. With regard to the pre-event window price reaction, companies were suffering poor performance for some time prior to the asset acquisition, suggesting this as the primary motivation for such activity. Using regression analysis support was found for "Fund Source Disclosure", "Fund Source Pecking-Order" and "Relative Size of Acquisition" hypotheses.

\section{References}

Afshar, K. A.; Taffler, R. J.; and Sudarsanam, P. S. 1992. The effect of corporate divestments on shareholder wealth: The U.K. experience. Journal of Banking and Finance 16 (1): 115-135.

Alexandrou, G., and Sudarsanam, S. 2001. Shareholders wealth effects of corporate selloffs: Impact of growth opportunities, economic cycle and bargaining power. European Financial Management 7(2): 237-258.

Asquith, P.; Bruner, R. F.; and Mullins, D. W. 1983. The gains to bidding firms from merger. Journal of Financial Economics 11: 121-139.

Boehmer, E.; Musumeci, J.; and Poulsen, A. B. 1991. Event-study methodology under conditions of event-induced variance. Journal of Financial Economics 30: 253-272.

Brown, S. J., and Warner, J. B. 1985. Using daily stock returns: The case of event studies. Journal of Financial Economics 14(1): 3-31.

Clubb, C., and Stouraitis, A. 2002. The significance of sell-off profitability in explaining the market reaction to divestiture announcements. Journal of Banking and Finance 26(4): 671-688.

Datta, S.; Iskandar-Datta, M.; and Raman, K. 2003. Value creation in corporate asset sales: The role of managerial performance and lender monitoring. Journal of Banking and Finance 27(2): 351-375.

Hayn, C. 1989. Tax attributes as determinants of shareholder gains in corporate acquisitions. Journal of Economics 23: 121-153.

Hite, G. L.; Owers, J. E.; and Rogers, R. C. 1987. The market for interim asset sales: Partial sell-offs and total liquidations. Journal of Financial 
Economics 18(2): 229-252.

Jain, P. C. 1985. The effect of voluntary sell-off announcements on shareholder wealth. Journal of Finance 40(1): 209-224.

Jarrell, G. A., and Poulsen, A. B. 1989. The returns to acquiring firms in tender offers: Evidence from three decades. Financial Management 18: 12-19.

Jensen, M.C. 1988. Agency costs of free cash flow, corporate finance, and the market for takeovers. American Economic Review 76: 323-329.

John, K., and Ofek, E. 1995. Asset sales and increase in focus. Journal of Financial Economics 37: 105-126.

Klein, A.1986. The timing and substance of divestiture announcements: Individual, simultaneous and cumulative effects. Journal of Finance 41: 685-696.

Lang, L. H. P.; Poulsen, A.; and Stulz, R. 1995. Asset sales, firm performance, and the agency costs of managerial discretion. Journal of Financial Economics 37(1): 3-37.

Lasfer, M. A.; Sudarsanam, P. S.; and Taffler, R. J. 1996. Financial distress, asset sales, and lender monitoring. Financial Management 25: 57-66.

Morck, R.; Shleifer, A.; and Vishny, R. W. 1990. Do managerial objectives drive bad acquisitions? Journal of Finance 45 (1): 31-48.

Myers, S. 1984. The capital structure puzzle. Journal of Finance 39: 575-592.

Myers, S. C., and Majluf, N. S. 1984. Corporate financing and investment decisions when firms have information the investors do not have. Journal of Financial Economics 13(2): 87-221.

Rosenfeld, J. D. 1984. Additional evidence on the relation between divestiture announcements and shareholder wealth. Journal of Finance 39: 1437-1448.

Sicherman, N. W., and Pettway, R. H. 1992. Wealth effects for buyers and sellers of the same divested assets. Financial Management 21: 119-128.

Slovin, M. B.; Sushka, M. E.; and Ferraro, S. R. 1995. A comparison of the information conveyed by equity carve-outs, spin-offs, and asset sell-offs. Journal of Financial Economics 37: 89-104.

Stulz, R.M. 1990. Managerial discretion and optimal financing policies. Journal of Financial Economics 26: 3-28.

Walker, M. M. 2000. Corporate takeovers, strategic objectives, and acquiring-firm shareholder wealth. Financial Management 29(1): 53-66.

White, H. 1980. A heteroskedasticity-consistent covariance matrix estimator and a direct test for heteroskedasticity. Econometrica 48: 817-838.

Zaima, J., and Hearth, D. 1985. The wealth effects of voluntary selloffs: Implications for divesting and acquiring firms. Journal of Financial Research 8: 227-236. 